\title{
A senses-based model for experiential tourism
}

\section{Um modelo baseado nos sentidos para turismo experiencial}

\author{
Luca Meacci \\ University of São Paulo, Brazil, luca.meacci@gmail.com \\ Giovanni Liberatore \\ University of Florence, Italy, giovanni.liberatore@unifi.it
}

\begin{abstract}
An experience can be defined as anything that stimulates the senses, heart and mind. Senses play a central role in individuals' perceptions of the surrounding world. Thus, research on tourist experiences' sensory dimensions is pivotal to improving visitor management in tourism. Recent studies have shown that successful tourism destinations attract tourists using a systematic approach to stimulating all the senses. This paper discusses the case of a multisensory criteria model applied to the tourism destination of Fiesole, Italy. The main aim was to provide a critical analysis of the various steps and outcomes of tourism experience design. The findings include a set of key tourism-related sensory experience concepts and the critical importance of following a logical order in experience processes. The results provided a theoretical framework that served as the foundation of a senses-based model, which not only provides an innovative focus within tourism research but also can function as a user-friendly tool for operators who need to plan, monitor and evaluate tourist experiences.
\end{abstract}

Keywords: Experiential tourism, destination management organisation (DMO) design, sensory model.

\section{Resumo}

Uma experiência pode ser definida como o estímulo desencadeado pela faculdade de sentir do coração e da mente. Os sentidos desempenham um papel central na nossa percepção do mundo circundante. Assim, o estudo da dimensão sensorial das experiências turísticas é fundamental para a gestão de visitantes no turismo. Estudos recentes mostraram que um destino turístico de sucesso deve atrair turistas através de uma abordagem sistemática baseada em estímulos para todos os sentidos. Este artigo discute um modelo de critérios multissensoriais aplicado ao destino turístico de Fiesole, Itália. O nosso objetivo é fornecer uma visão crítica das várias etapas e resultados de um projeto de experiência em turismo. Os resultados mostram que não apenas a coleta de conceitos experienciais dos sentidos, mas também a ordem lógica expressa pelo processo de experiência são fundamentais. Portanto fornecemos um enquadramento teórico para a origem de um modelo baseado nos sentidos, que além de ser um tema inovador, pode resultar numa ferramenta ágil para operadores planejarem, monitorarem, e avaliarem as experiências turísticas.

Palavras-chave: Turismo experiencial, desenho de organização de gerenciamento de destinos (DMO), modelo sensorial.

\section{Introduction}

The conventional tourism is in trouble. The birth and evolution of new forms of tourism, characterised by the tendency to depart from mass tourism, are facing new challenges (Stamboulis \& Skayannis, 2003). This change in tourism's attitude and behaviour calls for new approaches that use innovative ways to deliver services. In particular, researchers and economists have drawn attention to the experiential involvement of consumers (Holbrook, 2000; Pine \& Gilmore, 1999; Schmitt, 1999). Their findings related to hedonic value and emotional responses to consumption are especially relevant for tourism given the inherently experiential nature of tourism products and services (Gretzel \& Fesenmaier, 2003). In recent years, the provision of extraordinary experiences has become a strategic goal in the tourism industry (Walls, Okumus, Wang \& Kwun, 2011). In this context, analysing the sensory dimension of tourist experiences has recently been considered critical to support destination tourism planning (Agapito, Mendes \& Valle, 2013; Gilmore \& Pine, 2002; Gretzel \& Fesenmaier, 2010; Pan \& Ryan, 2009).

The role of human senses in enhancing travel experiences requires specific research (Agapito et al., 2013; Agapito, Mendes, Pinto \& Almeida, 2016; Mateiro, Kastenholz \& Breda, 2017; Rahmani, Gnoth \& Mather, 2018). Specifically, the evaluation and design of the tourist experience with a multisensory approach should be conceptualised by academic research.

This paper aims to contribute to this topic, presenting an original senses-based model for designing experiences with the purpose of promoting the personal engagement of visitors. For this purpose, we adopt a multidisciplinary methodology ad hoc designed and composed of the following steps. First, we investigate how senses play a crucial role in the experience from a multidisciplinary standpoint in accordance with the results presented by Agapito et al. (2013). Then, applying the touchpoint approach, we analyse how the interaction of all the senses makes the experience process. Eventually, we deduce that to design the product experience we need to plan experiential points using a comprehensive and holistic multisensory approach. Therefore, we describe in detail an original multisensory criteria model applied in a tourism destination. Finally, we present the application of this model in a case study (youtooscany.com).

\section{Senses in experience}

The role of senses in human life, experience and knowledge have been a reason for reflection since the early days of philosophy. The division and hierarchy of the senses into sight, 
followed by hearing, smell, taste and touch refer directly to Aristotle. He claimed that knowledge starts with sense perception through the apprehension (in the sense of learning or acquisition of knowledge) of the external world, and then an abstraction process allows the essence of objects to be captured.

In the eighteenth century, philosophers such as Kant defended the idea that knowledge of the world starts with the senses, evolving, however, through understanding and reasoning (Deleuze, 1994). Among the contemporary philosophical studies, we can find Merleau-Ponty, who, in Phenomenology of Perception, emphasises the role of the body in perception, stating that the world is perceived by the individual's body, rejecting the dualism of mind and body. Thus, the body is seen as a form of consciousness, its interactions with the world being what constitutes mental states and activities (Merleau-Ponty, 2002).

In the twentieth century, with the development of new sciences, the study of the importance of senses in the experience in understanding the world spread to many disciplines covering a wide range of academic fields.

Modern psychology considers that sensation involves mental processes necessary for the primary detection of the surrounding world, by which a stimulated sensor receptor creates a pattern of neural messages that represent the stimulus in the brain, initiating the individual's experience of the stimulus. Thus, psychologists approach the human senses assuming they are essential aspects of the person's experiences and behaviour (Davis \& Palladino, 2000; Goldstein, 2010; Zimbardo, Johnson \& Hamilton, 2011).

Furthermore, in neuroscience, in Descarte's Error, Damásio claims that the knowledge comes to the mind in the form of images. These images appear in all sensorial varieties, not only visual, but also sounds, textures, smells, tastes, pains and pleasures, and refer to any object or action that is being processed in the brain. During the perception process of events, individuals form perceptual images through external sensory stimuli captured by the human sensory sensors (Damásio, 2009; 2010).

Moreover, social anthropological studies on the social and cultural dimensions of the senses emphasise that perception stems from a learned behaviour in addition to being physically related and hostage to place and time (Howes, 2005). The historian Smith (2007, p. 3) affirms that "senses are historical, that they are not universal but, rather, a product of place and, especially, time so that how people perceived and understood smell, sound, taste, and sight changed historically".

In marketing management, the importance of human senses is evident in the individual's experience of different purchase and consumption processes. According to Schmitt (1999), one of the strategic experience modules is sensory itself (sense). Very recent marketing research confirms that products of all types can evoke strong sensory responses and consumption experiences that appeal directly to consumers (Howes \&
Classen, 2013). Krishna (2010, p. 332) affirms that "products are sensual in nature... The more a firm can create, accentuate, or highlight the sensuality of their products, the more appealing these products can be for consumers". The author defines "sensory marketing" as "marketing that engages the consumers' senses and affects their perception, judgment and behaviour" (Krishna, 2010, p. 332). Creating sensations, or bringing attention to existing sensations, can increase the appeal of products or services to consumers (Malefyt, 2015). Business consultants Hultén, Broweus and Van Dijk (2009, p. 6) posit that recent sensory awareness has launched "a new epoch in marketing", where "the five senses will be at the centre of a firm's marketing strategy and tactics". They argue that sensory marketing supersedes mass and relationship marketing as it involves "heightened consumer involvement with objects on a personal level". The aim of marketers is to unite all the senses in a cascading effect and create a "supreme sensory experience" that wins over the consumer (Hultén et al., 2009, p. 6).

In tourism studies, the sensory dimension of the tourist experience is a recent area of research. The importance of senses in the tourist experience has received increasing attention only in the last few years, but most of the studies have been centred on specific senses. Agapito et al. (2013) cite, for example, Adler's (1989) study on sight, Pocock's (2011) study on touch, Pilcher, Newman and Manning's (2009) work on hearing, Dan and Jacobsen's (2003) work on smell, and Hjalager and Richards' (2002) research on taste.

Until the 1990s, sight was considered the predominant sense in the tourist experience; however, all the senses together help the visitor to establish a relationship with the external environment and to give a meaning to the destination in which the experience takes place (Lindstrom, 2005; Markwell, 2001; Mateiro et al., 2017). Rejecting the hegemony of sight, the geographer Porteus (1986) coined the term 'sensescape' to highlight that the relationship between the body, people and places cannot have only a visual connotation, but a multisensory one as all the senses can be place-related. In the second edition of The Tourist Gaze, Urry (2002) developed the concept of 'sensescape', emphasising the importance in a tourist experience of involving not only the view and therefore the 'landscapes', but also the other sensory modalities, such as 'soundscapes', 'smellscapes', 'tastescapes', and 'geographies of touch' (Urry, 2002) or 'skinscapes' (Howes, 2005) to fully perceive the environment (Agapito et al., 2013; Agapito, Valle \& Mendes, 2012; Ellis \& Rossman, 2008; Govers, Go \& Kumar, 2007; Gretzel \& Fesenmaier, 2003; Kastenholz, Carneiro, Marques \& Lima, 2012; Urry, 2002).

There is no doubt that not only are all the senses equally important (Pan \& Ryan, 2009) but also there are powerful phenomena of interaction between them (Krishna, 2012). Some recent studies on consumer behaviours investigated crossmodal interactions, including the effects of smell and sound (Mattila \& Wirtz, 2001), sound and vision (Russell, 2002), sound 
and smell (Spangenberg, Grohmann \& Sprott, 2005), sound and perceived taste (Yorkston \& Menon, 2004), touch and taste (Krishna \& Morrin, 2008), vision and taste (Hoegg \& Alba, 2007), and smell and haptics (Krishna, Elder \& Caldara, 2010). As highlighted by Spence, Puccinelli, Grewal and Roggeveen (2014) in their studies on the impact of the retail stores' atmosphere on visitors' experiences and behaviours, the combined action of mono-sensory elements is greater than the sum of the values of the single elements in terms of the impact on and involvement of the person.

In this context, recent studies highlight the need to focus on all the bodily senses together (Agapito, Pinto \& Mendes, 2017; Mateiro et al., 2017). Mateiro et al. (2017) conducted a questionnaire-based survey on the sensory dimension of the tourist experiences in the Serra da Estrela Natural Park. On a five-point Likert scale, respondents indicated their view regarding the most important sense involved in their experience, followed by hearing, smell, taste and touch. The authors highlighted that even if senses acquire different importance in the tourist experience, they are all associated with the destination and can be exploited to create multisensory experiences and promote the natural park. Regarding the importance of the senses in making a tourist experience positive and memorable, Agapito et al. (2017) conducted a study on tourists' sensory experiences in southwest Portugal with a data collection process based on a survey presented for the first time in loco and then six months after the tourists' departure. In addition to open-ended questions about tourists' perception of their experiences in south-west Portugal, Mateiro et al. (2017) asked tourists to rank on a fivepoint Likert scale the level of agreement with the contribution of each sense to the achievement of a positive tourist experience. By comparing tourists' answers reported in loco and after the visit, the researchers found that there were no significant differences in responses and that all the senses reported positive ranks. Although in this study sight was the sensory aspect most referred to by respondents, the findings highlight the importance of the multisensory dimension in tourist experiences, especially regarding the effect on memorability. In fact, tourists who have perceived diversified sensory impressions were more likely to recommend and return to the destination. "The more senses an experience engages, the more effective and memorable it can be" (Pine \& Gilmore, 1998, p. 104). Therefore, the stimulation of the five senses in a tourist's experience can increase its retention in memory and lead to destination loyalty. Consequently, a holistic approach to the sensory dimension of the tourist experiences is needed. A successful tourism destination should attract tourists by more than visual stimuli and provide for all the senses (Agapito et al., 2017; Dann \& Jacobsen, 2002; Franklin \& Crang, 2001). As highlighted by Agapito et al. (2013), although at a theoretical level the holistic sensory approach is included and debated in a multidisciplinary vision, there are still few empirical studies in the field of experiential tourism. Understanding the factors influencing the sensory perception of the tourist experience is fundamental to be able to design the best experience possible. From this perspective, it may be interesting to critically analyse the experience of a specific tourist destination.

\section{A new way to see the experience process}

Every consumption event involves an interaction between a subject and an object (Holbrook, 1999), where the subject of interest is a consumer and the object of interest is a good, service, event, person, place or another type of thing. In their interaction, these two entities make different contributions to the overall consumption experience; however, both are important for the consumption event. In general, a product embodies certain features or objective characteristics, while the consumer embodies a personality equipped with sensitivity to various types of subjective responses. The consumption experience is created through this interaction, involving a strong relationship between the subject and the object (Addis \& Holbrook, 2001).

Therefore, in the case of experiential tourism, although the experience is usually treated as a product or object, it is crucial to recognise that the experience is a process of consumption where an event, the real object, became an experience. The experience occurs only when the objective characteristics of the event interact with the subjective responses of the protagonist (consumer) experience, as we can see in Figure 1.

Figure 1 - The experience process in tourism

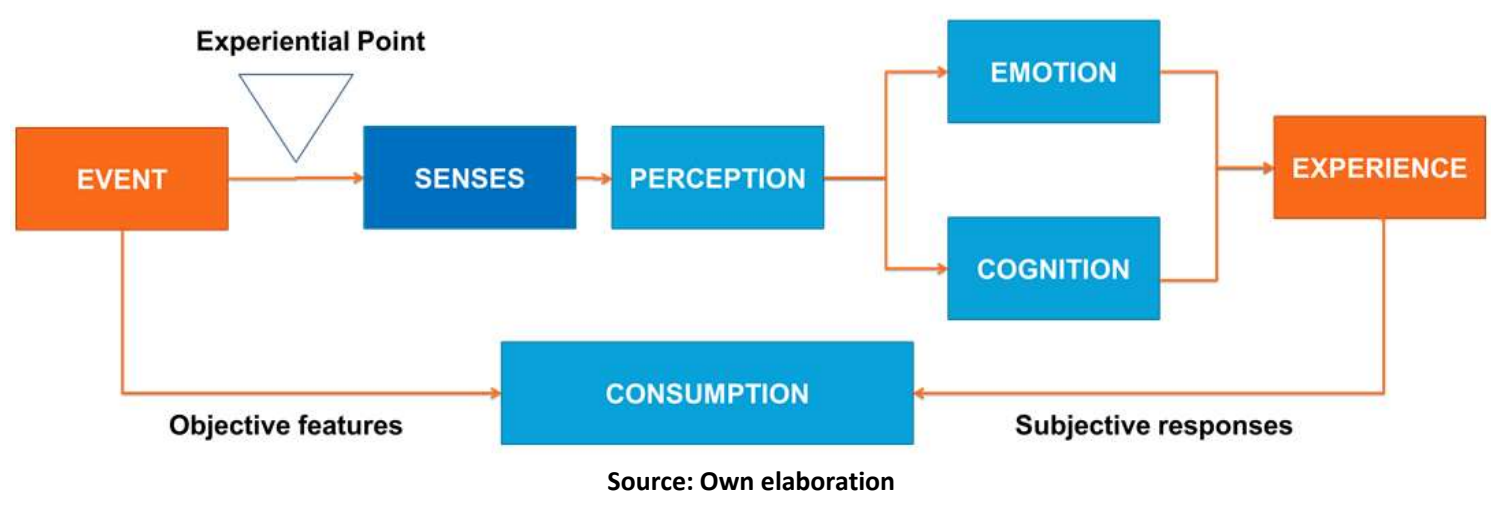


From a phenomenological and cognitive perspective, this experience process is composed of all the steps of a sequence that contribute to transforming the event into the experience itself (Volo, 2009). The first stage of the process is represented by senses. In fact, the process starts when the physical stimuli, caused by the event, impinge upon the receptor cells of the sensory organ of the tourist. This phase is biochemical and neurological in nature: an energy form impinges on a receptor physiologically designed to transduce it. The next stage is perception, which is the awareness or understanding of sensory information or, more simply, the interpretation of the sensation. In fact, in Latin, perceptio or percipio concerns the act of "apprehension with the mind or senses" (Ou, 2017). Psychologists tend to understand perception as a mental phase where sensory input is selectively attended to, organised and interpreted. Perception is about making sense of what our senses tell us (Larsen, 2007). Finally, perception affects emotion, the instinctive or intuitive inner state of the person related to feeling and cognition, the mental state of knowing, including aspects such as awareness, reasoning, and judgment (Krishna, 2012). This last phase is the most subjective and is the phase in which the tourist makes his/her own and internalises the experience. The event has become an experience.

By analysing the process, it can be concluded that senses have a crucial trigger role, being a sort of first and corporeal gateway in the experience process. Therefore, for the tourism industry, it is essential to leverage sensory stimuli to create a unique and memorable experience.

\section{A senses-based model}

Personal experiences are influenced by factors that are out of the control of management (Pullman \& Gross, 2004; Walls et al., 2011). As seen in the previous paragraph, these factors may include personal human interactions, cultural backgrounds and personality traits, and other personal factors. In other words, the individual who prepares the tourism offer has no influence on the subjective part of the process of experience.

This raises a question: 'How can an operator act to create experiences that are successful and fully involve tourists?'. The secret is to intervene in the right place in the process of experience where it triggers the subjective elaboration: the stimulation of the senses.

In marketing, the term 'touchpoint' is used to refer to the point or moment of contact between a product, service or brand with customers/users or other stakeholders. The touchpoint, which is also called 'moment of truth', is essentially the contact point between the object and the subject (Jenkinson, 2006, p. 251; 2007). Based on this concept, Rossi and Goetz (2011) define an experiential point as each point, a moment of contact or interaction between the consumer (tourist) and the event ( $a$ tourist destination or attraction) which can contribute to the overall tourism experience (Rossi \& Goetz, 2011). In Figure 1, the experiential point is placed at the start of the process as an element related to the event and an input into the senses. In this sense, we can affirm that each experiential point is sensual in nature and has a specific sensory dimension. This assumption makes it possible to move towards a crucial consequence: designing an experience means foreseeing, planning and creating experiential points. Therefore, a question arises later: 'How can an operator build experiential points?'.

Following the framework outlined in the current literature for which a holistic sensory approach to experiences is needed, we can deduce that designing the product experience means planning experiential points with a comprehensive and holistic multisensory approach.

The senses-based model presented here brings together the strategic elements discussed above and identifies the method for the design of a successful tourist experience in the following five actions:

(1) Identify and create multiple varied experiential points;

(2) Assign to each experiential point its sensory nature, that is, the primary sense associated with it;

(3) Give a score to every sense involved. Every sense is a dimension of valuation of the overall experience. This evaluation method was used by Agapito et al. (2017) and Mateiro et al. (2017) in their research, in which tourists were asked to rank the contribution of each sense to their tourist experience using a five-point Likert scale;

(4) Evaluate the effectiveness of the experience on the fivedimensional plane of the senses;

(5) If some sensory dimensions are characterised by low involvement, create new experiential points.

We note that an experience and the points of contact are different concepts. An experience would correspond to more experiential points. While an experience has a multisensorial nature, from the other side, the point of contact represents the connection between a specific objective characteristic of the experience and the sensorial receptor of the user of the experience. For this reason, we proceed to associate a single sense to each point. The act of itemising the experiential points is, therefore, a strategy oriented towards a more capillary evaluation of the sensorial dimensions. In fact, an experiential point will be more specifically defined to the extent that it will be closer to its connection with the sensor-receptor of the tourist.

This method, based on the model, therefore not only enables the evaluation of the impact of a tourist's experience but also the construction phase of the experience to guide the operator and helps to define, adjust and add contact points to guarantee an experience with full involvement.

In the next section, we present the application of this model using the youtooscany.com case as an example. 


\section{The youtooscany.com case}

The youtooscany project (financed by the Tuscany Region, Europen Regional Development Fund POR CREO FESR 2007-2013), which focuses on rural tourism in the hills of Florence, was established for competitive development of hospitality that aims to move from the concept of a common tourist product to that of an authentic tourist experience. The project has involved research centres such as the Centro Interuniversitario di Ricerca sul Turismo and the University of Florence, small and medium enterprises, such as the Farmhouse of Maiano, and Local Public Administrations, including the City of Fiesole. The goal of the project is to create a well-structured offer of tourism products that will be perceived as unique and engaging. At the same time, the purpose of this project is to provide this offer via an online experiential platform aimed not at a traditional traveller, which is limited to the simple search for the location or structure, but a new and more evolved user, who starts their online analysis with the search for a specific activity or a real experience in the territory.

On the home page of the website youtooscany.com, shown in Figure 2, large panoramic images with high resolution appear, so that the photos themselves, more than a text, depict the charm of Fiesole and Florence. The experiential purpose is suggested by all the elements. At the top left of the page, the logo composed of a stylised image of three cypresses, a symbol of the Tuscan landscape, on a ground inserted in a semi-circular space recalls forms related to the food and wine tradition of the territory as a glass or a plate. Moreover, the name of the site 'youtooscany' plays with the close assonance of the English word 'too' to the pronunciation of the first part of the word 'Tuscany', referring to the meaning 'you also in Tuscany'. Furthermore, underlining the strong experiential content, the central image includes the phrase: "Fiesole \& Florence Bound by Emotion". At the top right of the page, the tourist offer is articulated through the simple segmentation 'Do, Visit, Taste and Stay', making the contents within each theme easily perceived and facilitating the user navigation. In particular, the 'Do' section represents the central part of the whole platform, as it collects the experiences generated. Referring to this section, we test how the new senses-based model can contribute significantly to evaluating and then designing unique tourism experiences.

Figure 2 - The youtooscany.com home page

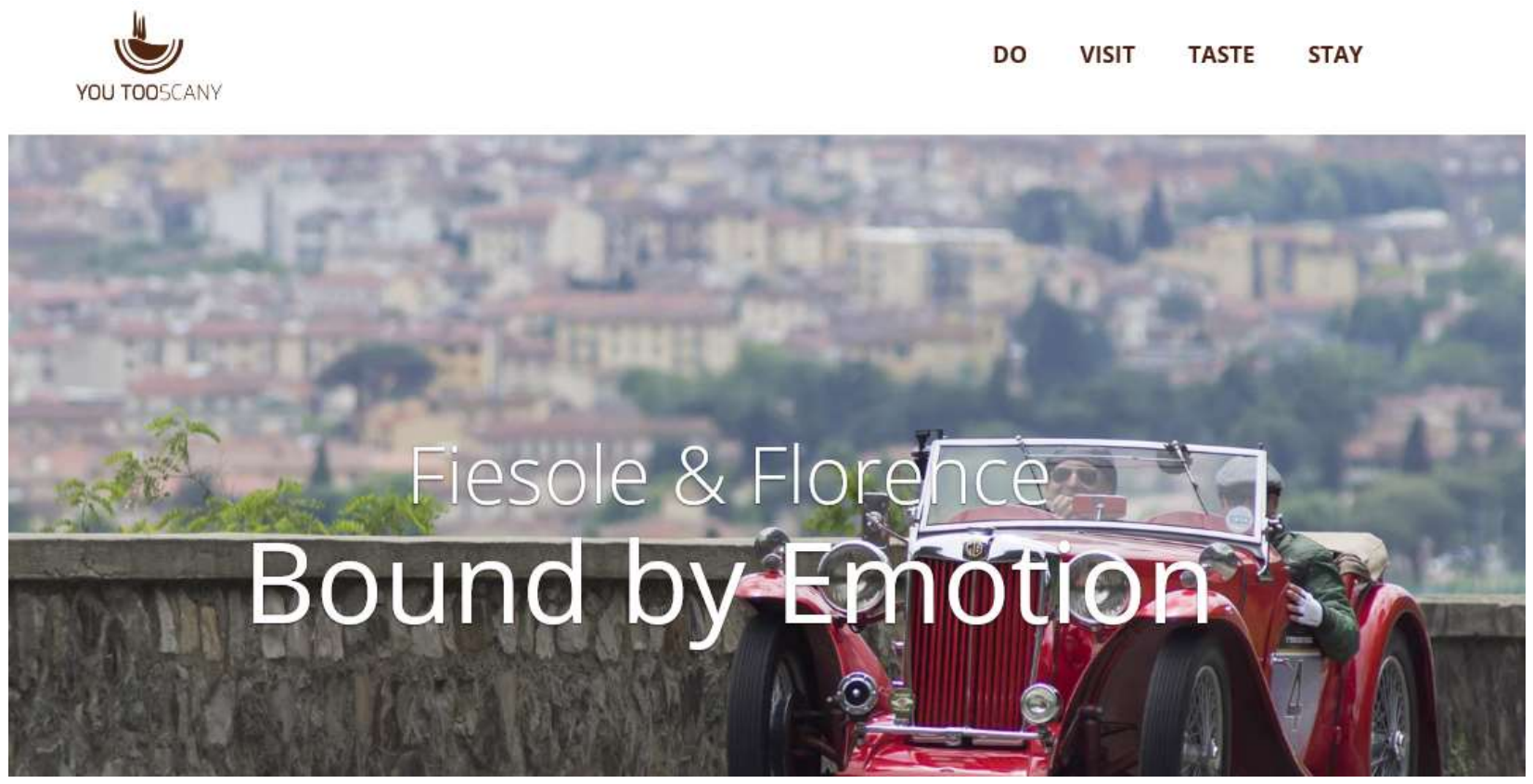

Source: https://youtooscany.com/

In the platform, every single experience is characterised in a simple and intuitive way by using an evocative title, an authentic image, and a short story about the proposed activity. For example, let us consider the experience 'Learn how to cook Tuscan with us' created within the project. The idea is to immerse the user quickly in the experience. In Figure 3, the presentation image is shown while the story reads: "Here, in Villa di Campolungo, we like to cook and share our traditional Tuscan recipes. This is why we provide cooking classes for our guests. Our cooking classes are adapted to adults, children, families, and small groups of friends. Cooking together is an experience that reinforces personal relations, brings calm to family relations and helps us get to know better our dear ones. The class lasts about four hours, during which the 'wannabe cooks' help to cook a menu including a starter (crostini or something else), a homemade pasta course (ravioli, tagliatelle, etc.) or a meat course and, finally, a dessert (almond biscuits, torta della nonna, etc.). At the end of the lesson, in the panoramic garden or in the room, the 'wannabe cooks' may finally taste the courses they have prepared from scratch accompanied by good local wine!". It is clear that the tourism product is presented with the awareness that the competitive advantage of a place is rooted in the evocative, cultural, emotional and multisensory contents that this place can 
suggest and transfer to the traveller. The senses-based model represents a tool for the evaluation (and therefore the construction/improvement) of this scenario and perspective at a specific and precise level.

Figure 3 - The application of the senses-based model to the youtooscany.com experience 'Learn how to cook Tuscan with us'

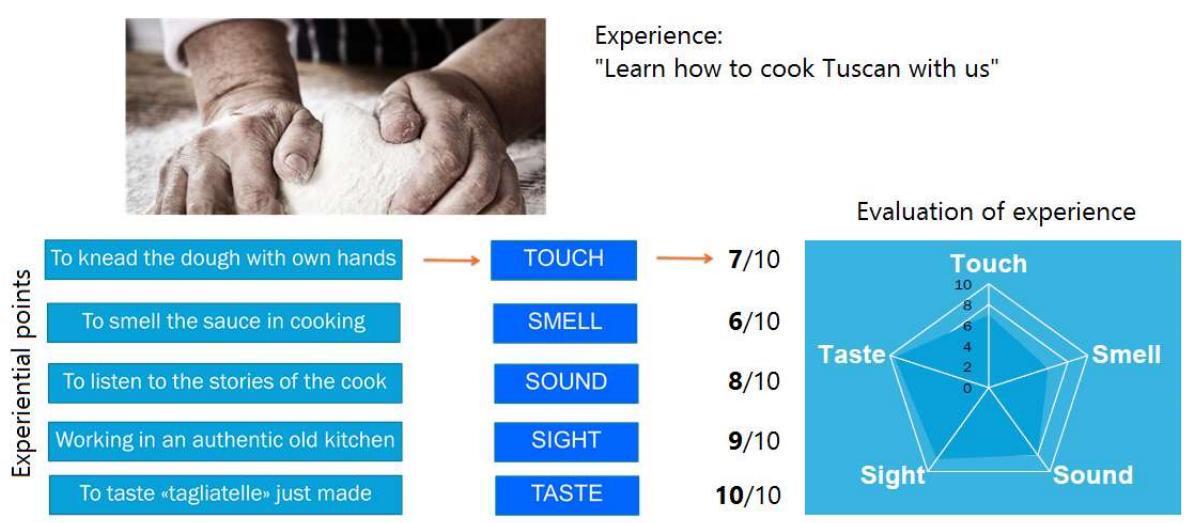

Source: Own elaboration modified from https://youtooscany.com/

Specifically, for the experience we are considering, we are going to show an application of the model.

Action (1) consists of identifying different experiential points. Some of these, as shown in the figure, are:

- To knead the dough with own hands

- To smell the sauce in cooking

- To listen to the stories of the cook

- Working in an authentic old kitchen

- To taste "tagliatelle" just made.

The experiential points listed above are just some of those that this experience provides. In reality, each experience contains many experiential points. However, they are considered sufficient to illustrate the application.

Action (2) relates the assignment to the sensory nature of each experiential point. Each of these points has a sensory nature which can be identified. In Figure 3, we have reported this association. It is evident, in this case, that all the senses are involved.

Action (3) has the goal of giving a score to every sense involved. This reflects the idea that every sense is a dimension in the evaluation of the experience. Giving a score to each experiential point, on the basis of the level of involvement of tourists regarding the respective sense, will enable the operator who designed and evaluates the experience to ascertain the effectiveness of the experience. This step introduces the next action.

Action (4) aims to evaluate the effectiveness of the experience on the five-dimensional plane of the senses. In this case, reporting the score values listed in Figure 3 on the sensory dimensions on the radar graph, the operator can have a more comprehensive overview and then an overall evaluation of the experience by considering the area of the resulting pentagon.

Action (5) is finally used to check whether some sensory dimensions are characterised by low involvement. If this occurs, any deficiency can be eliminated by creating new experiential points, i.e. enriching the proposed experience. It follows logically that in the case of many experiential points, each of them will have to be considered in the relative sensory dimension. The more experiential points an operator can create and the more the sensory dimensions are involved, the more meaningful, engaging, high-impact and successful the experience will be in terms of both consumer satisfaction and business. In fact, from the total quantification of the sensorial dimensions of the contact points, we obtain an estimate of the injection force of the experience process (presented in the previous section) seen as consumption action.

\section{Conclusions}

This work aims to contribute to the current research stream of the tourism experience, experiential consumption and the holistic approach using the case study methodology.

Relevant literature concerning tourism product integration recommends a new definition of the experience highlighting the crucial role of the senses. Several studies suggest that:

- Consumption is an interaction between a subject and an object;

- In tourism consumption, an event becomes an experience;

- Senses are the first and corporeal gateway in the experience process;

- Experiential points of contact (or touchpoints) between the consumer (tourist) and the event (tourist attraction) have to be analysed by DMOs;

- Each experiential point is sensual in nature and has a specific sensory dimension;

- It is not a single sensorial stimulus but the interaction between all the senses that makes the experience process; 
- Designing the product experience means planning experiential points using a comprehensive and holistic multisensorial approach.

In the analysis of the youtooscany.com case, we found that not only the gathering of tourism-senses experiential concepts but also the logical order expressed by the experience process is critical. Therefore, we have provided a theoretical framework for the foundation of a sensory-based model, which in addition to being an innovative subject of tourism research can result in an easy-to-use tool for operators to plan, monitor and evaluate tourist experiences.

\section{Acknowledgements}

Luca Meacci acknowledges with appreciation the Foundation CAPES (Coordenação de Aperfeiçoamento de Pessoal de Nível Superior) of the Ministry of Education of Federal Republic of Brazil for receiving economic support within the funding program (Financial code PROEX9740044/D) of academic excellence PROEX (Programa de Excelência Acadêmica). The same author thanks Izabel Cristina Alencar Cruz for the revision of the text in Portuguese but above all for her artistic sensibility and ability to see the things with "experiential" eyes.

\section{References}

Addis, M., \& Holbrook, M. B. (2001). On the conceptual link between mass customization and experiential consumption: An explosion of subjectivity. Journal of Consumer Behaviour, 1(1), 50-66.

Adler, J. (1989). Origins of sightseeing. Annals of Tourism Research, 16(1), 7-29.

Agapito, D., Mendes, J., \& Valle, P. (2013). Conceptualizing the sensory dimension of tourist experiences. Journal of Destination Marketing \& Management, 2(2), 62-73.

Agapito, D., Mendes, J., Pinto, P. \& de Almeida, H. (2016). The sensory dimension of consumer experiences in rural tourist destinations. Tourismos. An international multidisciplinary journal of tourism, 11 (4), 43-63.

Agapito, D., Pinto, P. \& Mendes, J., (2017). Tourists' memories, sensory impressions and loyalty: In loco and post-visit study in Southwest Portugal, Tourism Management, 58, 108-118.

Agapito, D., Valle, P. \& Mendes, J. (2012). Sensory marketing and tourist experiences. Spatial and Organizational Dynamics Discussion Papers, 10, 7-19 Retrieved July 30, 2012, from http://www.cieo.ualg.pt/discussionpapers/10/article1.pdf .

Damásio, A. R. (2009). O erro de Descartes: emação, razão e o cérebro humano. Editora Companhia das Letras.

Damásio, A. (2010). O Livro da Consciência: a Construçãodo Cérebro Consciente. [Self Comes to Mind: Constructing the Conscious Brain]. Lisboa: Temas e Debates/Círculo de Leitores.

Dann, G., \& Jacobsen, S. (2002). Leading the tourist by the nose. In G. Dann (Ed.), The tourist as a metaphor of the social world (pp. 209-217). New York: CABI Publishing.

Dann, G., \& Jacobsen, S. (2003). Tourism smellscape. Tourism Geographies, 5(1), 3-25.

Davis, S.F., \& Palladino, J.J. (2000). Psychology (3rd ed.). Upper Saddle River, N.J.: Prentice Hall.

Deleuze, G. (1994). A Filosofia Crítica de Kant. Lisboa: Ed.70.

Ellis, G.D., \& Rossman, J.R. (2008). Creating value for participants through experience staging: parks, recreation, and tourism in the experience industry. Journal of Park and Recreation Administration, 26(4), 1-20.

Franklin, A., \& Crang, M. (2001). The trouble with tourism and travel theory? Tourist Studies, 1(1), 5-22.
Gilmore, J. H., \& Pine, J. (2002). Differentiating hospitality operations via experiences why selling services is not enough. Cornell Hotel and Restaurant Administration Quarterly, 43(3), 87-96.

Goldstein, E.B. (2010). Sensation and perception (8 ed.). USA: Wadsworth.

Govers, R., Go, F., \& Kumar, K. (2007). Virtual destination image: a new measurement approach. Annals of Tourism Research, 34(4), 977-997.

Gretzel, U., \& Fesenmaier, D. (2003). Experience-based internet marketing: an exploratory study of sensory experiences associated with pleasure travel to the Midwest United States. In: A. Frew, M. Hitz, \& P. O'Connor (Eds). Information and communication technologies in tourism 2003 (pp.49-57).

Gretzel, U., \& Fesenmaier, D. (2010). Capturing sensory experiences through semi-structure delicitation questions. In: M. Morgan, L. Lugosi, \& J.R.B. Ritchie (Eds.), The tourism and leisure experience: consumer and managerial perspectives (pp.137-160). UK: Channel View Publications. Hjalager, A., \& Richards, G. (Eds.). (2002). Tourism and gastronomy. UK: Routledge.

Hoegg, J., \& Alba, J. W. (2007). Taste perception: More than meets the tongue. The Journal of Consumer Research, 33, 490-498.

Holbrook, M. B. (2000). The millennial consumer in the texts of our time: Experience and entertainment. Journal of Macromarketing, 20(2): 178-192.

Holbrook, M.B. (1999). Introduction to Consumer Value in Holbrook, M.B. (Ed). Consumer Value: A Framework for Analysis and Research. London: Routledge, 1-28.

Howes, D. (Ed.). (2005). Empire of the senses: the sensual culture reader. Oxford: Berg.

Howes, D., \& Classen, C. (2013). Ways of Sensing: Understanding the Senses in Society. New York: Routledge.

Hultén, B., N. Broweus, \& M. Van Dijk (2009). Sensory Marketing, Hampshire: Palgrave MacMillan.

Jenkinson, A (2006). Do organisations now understand the importance of information in providing excellent customer experience? Journal of Database Marketing \& Customer Strategy Management, Vol. 13, No. 4, pp. $248-260$.

Jenkinson, A (2007). Evolutionary implications for touchpoint planning as a result of neuroscience: A practical fusion of database marketing and advertising. Journal of Database Marketing \& Customer Strategy Management, Vol. 14, No. 3, pp. 164-185.

Kastenholz, E., Carneiro, M., Marques, C., \& Lima, J. (2012). Understanding and managing the rural tourism experience-the case of a historical village in Portugal. Tourism Management Perspectives, 4, 207-214.

Krishna, A. (2010). Sensory Marketing: Research on the Sensuality of Products. New York: Routledge.

Krishna, A. (2012). An integrative review of sensory marketing: Engaging the senses to affect perception, judgment and behavior. Journal of Consumer Psychology, 22, 332-351.

Krishna, A., \& Morrin, M. (2008). Does touch affect taste? The perceptual transfer of product container haptic cues. The Journal of Consumer Research, 34, 807-818.

Krishna, A., Elder, R. S., \& Caldara, C. (2010). Feminine to smell but masculine to touch? Multisensory congruence and its effect on the aesthetic experience. Journal of Consumer Psychology, 20(4), 410-418.

Larsen, S. (2007). Aspects of psychology of the tourist experience. Scandinavian Journal of Hospitality and Tourism, 7(1), 7-18.

Lindstrom, M. (2005). Brand sense: Build powerful brands through touch, taste, smell, sight and sound. New York: Free Press.

Malefyt, T. (2015). The senses in anthropological and marketing research: investigating a consumer-brand ritual holistically. Journal of Business Anthropology, 4(1), Spring.

Markwell, K. (2001). An intimate rendezvous with nature? Tourist Studies, 1(1), 39-57.

Mateiro, B., Kastenholz, E. \& Breda, Z. (2017). The sensory dimension of the tourist experience in mountain destinations: The case of Serra da 
Estrela Natural Park. Revista Turismo \& Desenvolvimento. 27-28, 20272038.

Mattila, A. S., \& Wirtz, J. (2001). Congruency of scent and music as a driver of in-store evaluations and behavior. Journal of Retailing, 77(2), 273-289.

Merleau-Ponty, M. (2002). Phenomenology of perception (trans. Colin Smith). London: Routledge and Kegan Paul.

Ou, Q. (2017). A Brief Introduction to Perception. Studies in Literature and Language, 15 (4), 18-28.

Pan, S., \& Ryan, C. (2009). Tourism sense-making: the role of the senses and travel journalism. Journal of Travel \& Tourism Marketing, 26(7), 625-639.

Pilcher, E., Newman, P., \& Manning, R. (2009). Understanding and managing experiential aspects of soundscapes at Muir Woods National Monument. Environmental Management, 43(3), 425-435.

Pine, J. \& Gilmore, J. (1998). Welcome to the Experience Economy. Harvard Business Review, 76 (4), 97-105.

Pine, J. \& Gilmore, J. (1999). The experience economy. Boston, MA: Harvard Business School Press.

Porteous, J. D. (1985). Smellscape. Progress in Physical Geography, 9, 356-378.

Pullman, M.E., Gross, M.A., (2004). Ability of experience design elements to elicit emotions and loyalty behaviors. Decision Sciences 35 (3), 551-578.

Rahmani, K., Gnoth, J. \& Mather, D. (2018). A Psycholinguistic View of Tourists' Emotional Experiences. Journal of Travel Research, 1-15.

Rossi, A. \& Goetz, M. (2011). Tourist Experience Design. Milano: HOEPLI. Russell, C.A. (2002). Investigating the effectiveness of product placements in television shows: The role of modality and plot connection congruence on brand memory and attitude. The Journal of Consumer Research, 29(3), 306-318.

Schmitt, B. (1999). Experiential Marketing. New York: The Free Press. Smith, M. (2007). Sensory history. Oxford: Berg.

Spangenberg, E. R., Grohmann, B., \& Sprott, D. E. (2005). It's beginning to smell (and sound) a lot like Christmas: The interactive effects of ambient scent and music in a retail setting. Journal of Business Research, 58(11), 1583-1589.

Spence, C., Puccinelli, N., Grewal, D., \& Roggeveen, A. L. (2014). Store Atmospherics: A Multisensory Perspective. Psychology \& Marketing, 31 (7), 472-488.

Stamboulis, Y., \& Skayannis, P. (2003). Innovation strategies and technology for experience-based tourism. Tourism Management, 24(1), 35-43.

Urry, J. (2002). The tourist gaze (2nd ed.). London: Sage Publications.

Volo, S. (2009). Conceptualizing experience: a tourist-based approach. Journal of Hospitality Marketing \& Management, 18:111-126, Routledge.

Walls, A., Okumus, F., Wang, Y., \& Kwun, D. (2011). An epistemological view of consumer experiences. International Journal of Hospitality Management, 30(1), 10-12.

Yorkston, E., \& Menon, G. (2004). A sound idea: Phonetic effects of brand names on consumer judgments. The Journal of Consumer Research, 31(1), 43-51.

Zimbardo, P., Johnson, R., \& Hamilton, V.M. (2011). Psychology: core concepts ( $7^{\text {th }}$ ed.). USA: Pearson.

Received: 20.12.2017

Revisions required: 16.04 .2018

Accepted: 26.06.2018 